\title{
Kepemimpinan Keselamatan, Komitmen Ahli K3, Akuntabilitas Terhadap Kepuasan Kerja dan Kinerja Keselamatan
}

\author{
Gatot Sutrisno ${ }^{1}$, Tatan Sukwika,"* \\ ${ }^{1}$ Universitas Sahid Jakarta, larsogs0604.lgs@gmail.com \\ ${ }^{2}$ Universitas Sahid Jakarta, "tatan.swk@gmail.com
}

\begin{abstract}
The incidence of work accident rates tends to be volatile due to ineffective patterns of cooperation and communication between employees and leaders understanding OHS. The purpose of this study is to examine safety leadership, the commitment of OHS experts, accountability to job satisfaction \& safety performance. The research analysis method used the PLS or partial least square modeling test. Data collection using questionnaire answer results with a sample of 99 employees. The results show that job satisfaction is significantly affected by safety leadership, and OHS expert commitment and responsibility and safety performance are affected by safety leadership and job satisfaction. The variable commitment and accountability of OHS experts have no significant impact on company performance. The conclusion found workers were satisfied that safety leadership, OHS expert commitments, and accountability could be applied, resulting in improved safety performance. On the other hand, OHS experts have no commitment and accountability to improve safety performance. This situation is due to workers' lack of commitment to implementing OHS and accountabilities. Managerial implications require the OHS aspect to be an integral part of the company's operations and the consequences for improving safety performance standards.
\end{abstract}

Keywords: leadership, OHS expert, accident, accountability, performance

\begin{abstract}
ABSTRAK
Kejadian tingkat kecelakaan kerja cenderung fluktuatif akibat tidak efektifnya pola kerjasama dan komunikasi antara karyawan dan pimpinan memahami K3. Tujuan studi ini mengkaji kepemimpinan keselamatan, komitmen ahli K3, dan akuntabilitas terhadap kepuasan kerja dan kinerja keselamatan. Metode analisis penelitian digunakan uji pemodelan .PLS atau partial least square. Pengumpulan data menggunakan hasil jawaban kuesioner dengan sampel karyawan berjumlah 99 orang. Hasilnya diketahui bahwa kepuasan kerja dipengaruhi secara signifikan oleh kepemimpinan keselamatan, komitmen ahli K3 dan akuntabilitas, begitu pula kinerja keselamatan dipengaruhi oleh kepemimpinan keselamatan dan kepuasan kerja. Sementara pada variabel komitmen ahli K3 dan akuntabilitas tidak ditemukan pengaruh yang signifikan pada kinerja perusahaan. Kesimpulan menemukan pekerja merasa puas jika kepemimpinan keselamatan, komitmen ahli K3, dan akuntabilitas dapat diterapkan dengan baik, sehingga kepuasan kerja berdampak pada peningkatan kinerja keselamatan. Di lain sisi, belum ditemukan komitmen ahli $\mathrm{K} 3$ dan akuntabilitas mampu meningkatkan kinerja keselamatan. Kondisi ini akibat kurangnya komitmen pekerja dalam penerapan K3, begitu pula akuntabilitas. Implikasi manajerialnya dibutuhkan berupa penempatan aspek K3 sebagai bagian integral operasi perusahaan dan konsekuensi untuk peningkatan standar kinerja keselamatan.
\end{abstract}

Kata Kunci : kepemimpinan, ahli K3, kecelakaan, akuntabilitas, kinerja

Naskah diterima: 30-08-2021, direvisi: 25-08-2021, diterbitkan: 01-09-2021

ISSN: 2355-0295, e-ISSN: 2549-8932 


\section{PENDAHULUAN}

Kinerja keselamatan dapat dilihat dari seberapa perusahaan mampu mengurangi tingkat kecelakaan kerja dalam periode tertentu, hal ini telah tergambarkan bahwa kejadian kecelakaan kerja kategori ringan pada tahun 2018 sebanyak 63 kejadian/orang, untuk tahun 2019 sebanyak 85 kejadian/orang dan pada tahun 2020 sebanyak 30 kejadian/orang. Hal ini kecelakaan kerja tersebut selama tiga tahun terakhir cenderung fluktuatif.

Komitmen ahli K3 (keselamatan dan kesehatan kerja) secara keseluruhan belum merata dalam memberikan arahan terkait kebijakan K3 kepada pekerja, sehingga kinerja keselamatan masih belum optimal secara menyeluruh karena tingkat kebutuhan dan perhatian pada setiap individu berbeda. Kondisi tidak aman menyebabkan terjadinya kecelakaan kerja pada karyawan yang ceroboh, tidak patuh pada prosedur kerja, tidak menggunakan APD atau alat pelindung diri yang lengkap, menghiraukan instruksi kerja dan tidak melaporkan adanya kerusakan mesin pada saat/sedang bekerja (Kartikasari \& Sukwika, 2021; Purba \& Sukwika, 2021). Perusahaan perlu mendorong komitmen internalnya, guna menjelaskan dan mendukung pengembangan para karyawannya (Darmawan \& Putri, 2017; Prasetyaningrum, 2020; Riswanto, 2014; Widiarti \& Dewi, 2016; Zahra, 2015).

Akuntabilitas belum sepenuhnya merata dilakukan oleh karyawan terkait (person incharge), sehingga kinerja keselamatan belum sesuai keinginan dan harapan. Beberapa hal lain yang belum sepenuhnya dilakukan antara lain: mendorong karyawan untuk tetap mematuhi dan mengikuti SMK3 (sistem manajemen keselamatan dan kesehatan kerja), melakukan pertemuan keselamatan (safety meeting) dengan karyawan terutama kepada karyawan terdampak kecelakaan kerja, melakukan kontak harian kepada pekerja di lapangan, mengadakan safety talk kepada karyawan secara berkala, memberikan pelatihan secara periodik dan tercatat tentang praktek keja aman dan pelatihan terkait keselamatan lainnya (Fajri et al., 2017; Mulyono, 2013;
Pramudya, 2018; Purba \& Sukwika, 2021; Satoto, 2020).

Aspek penting lain sebagai pilar dalam menerapkan budaya $\mathrm{K} 3$ dalam organisasi kerja salah satunya dengan menerapkan komitmen dari pimpinan sebagai penentu kebijakan. Kepemimpinan suatu bentuk budaya kerja untuk mengubah sikap karyawannya memiliki motivasi yang bertujuan guna mewujudkan prestasi kerja (Agustina \& Sukwika, 2021; Kartikawati et al., 2014).

Kepemimpinan keselamatan memiliki peran untuk mencapai tujuan membangun budaya keselamatan dalam pekerjaannya yang dapat meningkatkan kinerja kepemimpinan keselamatan serta menjadi bagian seorang pimpinan sebagai keberhasilan kinerja K3 (Purba \& Sukwika, 2021; Satoto, 2020). Kepemimpinan memainkan peranan penting meningkatkan kinerja. Dengan kata lain, unjuk kerja harus memperhatikan kelompok dalam manajemen secara menyeluruh, sehingga kepemimpinan dianggap mampu meningkatkan kinerja dan kepuasan kerja karyawan yang bekerja (Darmawan \& Putri, 2017; Mulyono, 2013).

Kepuasan kerja terbukti memiliki hubungan dengan komitmen organisasi, maka perlu menjadi suatu bagian yang dapat menyebabkan perilaku mengubah fungsi dan komitmen organisasi. Kepemimpinan keselamatan merupakan faktor utama dalam menerapkan dan menjalankan SMK3 (sistem manajemen keselamatan dan kesehatan kerja), karena sebaik apapun SMK3 yang ada di perusahaan tidak akan berjalan dan tidak mungkin menarik keterlibatan karyawan untuk berkomitmen menjalankan aktivitas keselamatan secara menyeluruh, komitmen akan tercermin pada sikap dan tindakannya (Fajri et al., 2017; Mulyono, 2013; Pramudya, 2018; Purba \& Sukwika, 2021; Ramli, 2010; Sunarta, 2019).

Komitmen merupakan bagian dari sikap karyawan terhadap pekerjaannya sehingga mampu berkontribusi pada perusahaan dengan kebijakan-kebijakan yang terdapat di organiasinya karena adanya kesamaan nilainilai yang dianutnya dengan nilai-nilai organisasinya. Keberadaan komitmen bersama pada organisasi dapat menentukan tingkat 
kepuasan pekerja dan komitmen dalam memajukan organisasi (Prasetyaningrum, 2020; Riswanto, 2014; Widiarti \& Dewi, 2016; Zahra, 2015). Didasarkan pemaparan di atas maka permasalahan yang dapat dirumuskan pada penelitian ini yaitu seberapa besar kepuasan kerja dan kinerja keselamatan dapat dipengaruhi dengan baik oleh kepemimpinan keselamatan, komitmen ahli K3, dan akuntabilitas. Tujuan penelitian menguji pengaruh kepemimpinan keselamatan, komitmen ahli K3, dan akuntabilitas terhadap kepuasan kerja dan kinerja keselamatan.

\section{KAJIAN LITERATUR}

\section{Kepemimpinan keselamatan pada} kepuasan kerja dan kinerja keselamatan

Kepemimpinan K3 dalam hal ini yaitu sebagai pemimpin mampu mengubah sebuah organisasi/perusahaan dengan cara mengarahkan dan menerapkan tujuan organisasi/perusahaan yang mampu memberikan inspirasi bagi seluruh karyawan untuk mencapai visinya tersebut (Marzuki et al., 2018; Mulyono, 2013; Widiarti \& Dewi, 2016). Kepemimpinan individu maupun kepemimpinan dalam perusahaan memainkan peranan penting meningkatkan kinerja. Dengan kata lain, unjuk kerja harus memperhatikan kelompok dalam manajemen secara menyeluruh, sehingga kepemimpinan dianggap mampu meningkatkan kinerja karyawan dan kepuasan kerja karyawan yang bekerja di tempat tersebut (Darmawan \& Putri, 2017; Mulyono, 2013; Zahra, 2015).

\section{Komitmen ahli K3 pada kepuasan kerja dan kinerja keselamatan}

Perusahaan perlu mendorong komitmen internalnya, guna menjelaskan dan mendukung pengembangan para karyawannya. Manajemen perusahaan juga perlu melibatkan pekerja untuk menentukan tujuan kerjanya. Tetapi dalam mengontrol kontribusi pekerja guna mendukung tujuan organisasi maupun perusahaan memerlukan pemberdayaan para karyawannya, hal ini karena karyawan yang dapat diberdayakan akan meningkatkan kepercayaan pada bisnis, memahami apa yang seharusnya dilakukan oleh dirinya dan bersedia untuk memberikan ide-ide yang cemerlang untuk memajukan perusahaan (Darmawan \& Putri, 2017; Jamal et al., 2021; Prasetyaningrum, 2020; Riswanto, 2014). Perhatian utama dalam memajukan perusahaan yaitu memperhatikan dan meningkatkan kepuasan kerja para karyawannya, karena jika karyawan kurang merasa dihargai, dinilai belum mampu atas kinerja/hasil kerja yang mereka miliki, maka tidak akan merasa puas. Keberhasilan dalam pekerjaan bukan menjadi salah satu dari kepuasan kerja, ada hal-hal lainnya seperti melakukan interaksi dengan sesama rekan kerja, dengan pimpinan, mengikuti peraturan perusahaan dan lingkungan kerja yang seringkali tidak memadai. Komitmen dalam sebuah organisasi adalah salah satu pengabdian dan tanggung jawab bersama yang menjadi kunci sukses dalam organisasi sehingga mampu mempengaruhi kinerja karyawan (Mulyono et al. 2013; Riswanto, 2014).

\section{Akuntabilitas pada kepuasan kerja dan kinerja keselamatan \\ Akuntabilitas akan mampu} meningkatkan kualitas kerja perusahaan yang berdampak bagi kepentingan publik secara langsung maupun tidak langsung, hal ini menjadi bagian dari suatu tujuan dalam pelayanan publik yang baik (Radiyanto, 2018; Wardiana \& Hermanto, 2019).

Akuntabilitas yaitu kewajiban pihak pemegang amanah dalam suatu perusahaan yang menjadi bagian tanggungjawabnya pada seluruh aktivitas kegiatan yang dilakukan. Selanjutnya perusahaan memiliki hak dan kewajiban yang diberikan kepada pemegang amanah untuk menindaklanjuti tanggung jawabnya. Akuntabilitas memiliki pengaruh yang kuat terhadap kinerja organisasi (Jamal et al., 2021; Radiyanto, 2018; Sunarta, 2019; Wardiana \& Hermanto, 2019).

\section{Kepuasan kerja pada kinerja keselamatan}

Kepuasan kerja keterkaitannya terhadap pekerjaan dapat memberikan situasi dan perasaan yang menyenangkan atas kegiatan pekerjaan yang dilakukan, rasa nyaman, rasa aman dan kesehatan dapat terjaga. Dalam lingkup perusahaan bila karyawan merasakan atas kepuasan kerjanya maka dapat 
meningkatkan produktivitas dan kinerja (Sunarta, 2019). Beberapa penelitian lain menunjukkan bahwa kepuasan kerja menjadi dasar kinerja karyawan dan kepuasan kerja memiliki pengaruh kuat pada kinerja (Fajri et al., 2017; Mulyono, 2013; Pramudya, 2018).

\section{Kepemimpinan keselamatan pada kinerja keselamatan melalui kepuasan kerja}

Perilaku seorang pemimpin yaitu sebagai faktor penting yang mampu memberikan dampak pada kepuasan kerja. Agar kepuasan kerja timbul dan dapat dirasakan oleh karyawan dalam bekerja, sebagai penyelia mendengakan keluhan yang dialami karyawan dalam aspek pekerjaannya dan selalu memberikan solusi penyelesaiannya. Kepuasan kerja dan kinerja karyawan di perusahaan dapat meningkat ditunjukan pada sikap seseorang memiliki kemampuan kepemimpinan yang baik (Darmawan \& Putri, 2017; Kartikawati et al., 2014; Mulyono, 2013; Satoto, 2020; Zahra, 2015).

\section{Komitmen ahli K3 pada kinerja keselamatan melalui kepuasan kerja}

Keberhasilan setiap pekerja ditentukan oleh kompetensi, kemahiran dan komitmen terhadap pekerjaan yang dilakukannya. Komitmen organisasi akan terlihat dari sikap seseorang karena dirinya menjadi bagian dari perusahaan dan selalu memberikan kontribusi untuk memajukan kegiatan perusahaan. Oleh karena itu komitmen perusahaan akan timbul secara langsung karena karyawan merasa memiliki dan terlibat dalam suatu kegiatan perusahaan. Komitmen organisasi mampu meningkatkan kinerja melalui kepuasan kerja karyawan pada perusahaan (Jamal et al., 2021; Pramudya, 2018; Prasetyaningrum, 2020; Riswanto, 2014; Satoto, 2020).

\section{Akuntabilitas pada kinerja keselamatan melalui kepuasan kerja}

Kinerja yaitu gambaran hasil kerja secara kualitas dan kuantitas yang dicapai oleh seseorang dalam melaksanakan tugasnya didalam perusahaan sesuai dengan tanggung jawab yang diberikan kepadanya. Akuntabilitas berpengaruh terhadap kinerja setiap perusahaan atau organisasi jika dilakukan dengan penuh tanggung jawab, maka dapat dikatakan sebagai pemerintahan yang baik. Akuntabilitas mampu meningkatkan kepuasan kerja dengan prestasi kerja pegawai (Radiyanto, 2018; Wardiana \& Hermanto, 2019).

\section{Hipotesis Penelitian}

Berdasarkan tinjauan pustaka dan kerangka pemikiran yang tersaji pada gambar 1, maka hipotesis penelitian diajukan hipotesis bahwa diduga kepemimpinan keselamatan, komitmen ahli K3, akuntabilitas berdampak terhadap kepuasan kerja dan kinerja keselamatan.

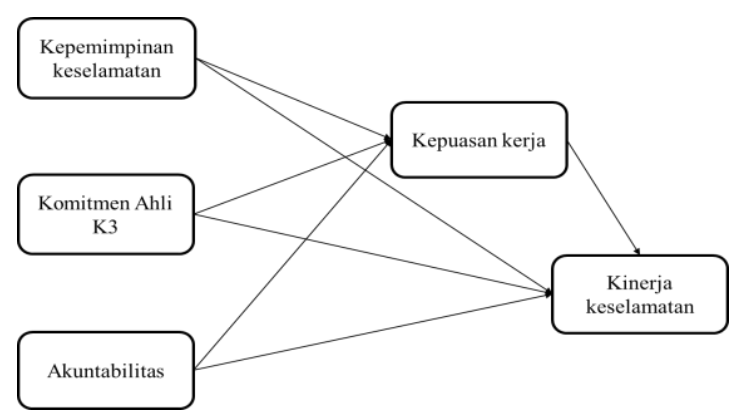

Gambar 1. Kerangka pemikiran

\section{METODE PENELITIAN}

Pada bagian metode penelitian terlebih dahulu dilakukan disain riset sebagai proses mengusun kerangka kerja atau rencana untuk melakukan studi yang digunakan sebagai pedoman dalam mengumpulkan dan menganalisis data. Disain penelitian dalam penelitian ini digunakan penelitian eksploratif, deskriptif, dan kasual. Penelitian eksploratif bertujuan untuk menyelidiki suatu masalah atau situasi untuk mendapatkan pengetahuan dan pemahaman yang baik. Sementara itu, penelitian deskriptif bertujuan untuk menggambarkan sesuatu. Penggunaan disain penelitian deskriptif diharapkan output penelitian memiliki pernyataan yang jelas mengenai permasalahan yang dihadapi, hipotesis yang spesifik, dan informasi detail yang dibutuhkan. Terakhir, desain riset kausal lebih menekankan pada penentuan hubungan sebab dan akibat, yaitu untuk mengetahui peubah yang menjadi penyebab (independent 
variable) dan peubah akibat (dependent variable) dari suatu fenomena.

Gambaran umum lokasi penelitian, perusahaan yang diteliti berada di kawasan industri EJIP Cikarang selatan kabupaten Bekasi Jawa Barat. Sebagai perusahaan yang berada di dalam kawasan industri, dalam aktivitas operasionalnya menyediakan fasilitas lengkap dan baik untuk mendukung kinerja karyawan dengan manajemen pengelolaan dan operasional oleh $100 \%$ tenaga kerja Indonesia.Dengan pengalaman terbaik dibidang peralatan \& sistem kelistrikan yang didukung penuh $\mathrm{R} \& \mathrm{D}$ (Litbang) menjamin penuh kualitas yang di produksi sesuai dengan kebutuhan public. Mendukung penuh kebijakan pemerintah dalam program TKDN (Tingkat Kandungan Dalam Negeri), pada tahun 2008 dan berhasil mendapatkan sertifkat TKDN untuk jenis peralatan listrik tertentu. Di tahun 2009 dan seterusnya, lokalisasi komponen terus dilakukan untuk meningkatkan tingkat kandungan lokal produk meter listrik lainnya. Perusahaan memiliki komitmen penuh terhadap konsep manufaktur yang ramah lingkungan dengan pemakaian sumber daya yang efisien dan pencegahan terhadap kerusakan lingkungan yang disebabkan aktifitas produksi serta memberikan prioritas utama kepada keselamatan kerja dan kesehatan. Perusahaan yang diteliti bergerak di bidang lingkungan, sehingga untuk pengelolaan kawasan demi kenyamanan dan hubungan masyarakat, maka perusahaan memiliki program corporate social responsibility (CSR).

\section{Populasi dan sampel}

Populasi yang digunakan pada penelitian yaitu sejumlah 293 responden. Penentuan karakteristik responden dengan kriteria yaitu:

Tabel 1. Populasi Penelitian

\begin{tabular}{clc}
\hline No & Karakteristik /Bagian & Jumlah \\
\hline 1 & Departemen head (Dh) & 7 \\
\hline 2 & $\begin{array}{l}\text { Engineer, Supervisor, Staff/Officer } \\
\text { dan Leader group \& Operator } \\
\text { (Eng, Svr, SO, LO) }\end{array}$ & 277 \\
\hline 3 & Penanggung jawab HSE memiliki & 9
\end{tabular}

sertifikat Ahli K3 di perusahaan (AK3U \& lainnya) (Pj.K3)

Total keseluruhan (orang)

293

Sumber: Hasil Analisis Penulis (2021)

Besarnya ukuran sampel bergantung jenis penelitian dan pengambilan sampelnya, perhitungan sampel mengikuti jenis penelitiannya yaitu sebagai berikut (Ruseffendi, 2010):

$$
\begin{gathered}
\frac{\text { Jumlah Karakteristik/Bagian }}{\text { Total Jumlah Keseluruhan Karyawan }} \times 100 \% \\
\text { Dh }=\frac{7}{293} \times 100 \%=2 \text { orang } \\
\text { Eng,Svr, SO, LO }=\frac{277}{293} \times 100 \%=94 \text { orang } \\
\text { Pj. K3 }=\frac{9}{293} \times 100 \%=3 \text { orang }
\end{gathered}
$$

Berdasarkan perhitungan sampel di atas dan untuk memudahkan penelitian, maka jumlah penelitian untuk karakteristik/bagian Departemen Head sebanyak 2 orang, untuk karakteristik/bagian Engineer, Supervisor, Staff \& Officer dan Leader group \& Operator sebanyak 94 orang dan untuk karakteristik/bagian Penanggung jawab K3 memiliki sertifikat Ahli K3 di perusahaan sebanyak 3 orang. Jumlah sampel dalam penelitian dari perhitungan yaitu sebanyak 99 orang.

\section{Definisi operasional variabel}

Variabel eksogen merupakan variabel yang memberikan dampak timbulnya variabel endogen, variabel eksogen yaitu kepemimpinan keselamatan, komitmen ahli K3 dan akuntabilitas. Variabel intervening merupakan variabel yang mempengaruhi hubungan antara variabel eksogen terhadap variabel endogen, variabel intervening yaitu kepuasan kerja. Variabel endogen ini adalah variabel yang dipengaruhi karena adanya variabel eksogen, variabel endogen yaitu kinerja keselamatan.

\section{Metoda analisis data}

Metode analisis data menggunakan program komputer yang dilakukan dengan tiga analisis diantaranya yaitu outer model, inner model, dan pengujian hipotesis. Dengan metode tersebut akan diketahui data 
dinyatakan valid dan dapat pula diketahui variabel yang mampu mempengaruhi.

\section{Analisis Outer Model}

1. Convergent Validity: ketentuan valid jika nilai outer loading $>0,07$.

2. Discriminant Validity: ketentuan nilai loading yang dituju > nilai loading lainnya.

3. Average Variance Extracted (AVE): ketentuan nilai rata-rata $\mathrm{AVE}>0,5$.

4. Composite Reliability: ketentuan composite reability $>0,07$.

5. Cronbach Alpha: ketentuan cronbach alpha $>0,7$.

\section{Analisis Inner Model}

1. Koefisien Determinasi (R2): semakin mendekati $100 \%$ lebih besar pengaruhnya.

2. Effect Size (f2): mendekati angka 1 menjadikan penilaian prediksi yang semakin baik

3. Penilaian Goodness of Fit (GoF): penelitian layak uji dengan model PLS atau partial least square jika nilai SRMR < 0,08 .

\section{Hipotesis Penelitian}

H1: Adanya pengaruh kepemimpinan keselamatan terhadap kepuasan kerja.

$\mathrm{H} 2$ : Adanya pengaruh komitmen ahli K3 terhadap kepuasan kerja.

H3: Adanya pengaruh akuntabilitas terhadap kepuasan kerja.

H4: Adanya pengaruh kepemimpinan keselamatan terhadap kinerja keselamatan.

H5: Adanya pengaruh komitmen ahli K3 terhadap kinerja keselamatan.

H6: Adanya pengaruh akuntabilitas terhadap kinerja keselamatan.

H7: Adanya pengaruh kepuasan kerja terhadap kinerja keselamatan.

H8: Adanya pengaruh kepemimpinan keselamatan terhadap kinerja keselamatan melalui kepuasan kerja.

H9: Adanya pengaruh komitmen ahli K3 terhadap kinerja keselamatan melalui kepuasan kerja.

H10: Adanya pengaruh akuntabilitas terhadap kinerja keselamatan melalui kepuasan kerja.
Adapun indikator instrumen variabel penelitian yang terdiri dari variabel kepemimpinan keselamatan (KS), komitmen Ahli K3 (KAK), akuntabilitas (A), kepuasan kerja (KKJ) dan kinerja keselamatan (KKS) serta masing-masing indikator memiliki item indikator variabel penelitian yang telah dirangkum mengikuti Tabel 2 dibawah ini:

Tabel 2. Indikator Instrumen Penelitian

\begin{tabular}{|c|c|}
\hline $\begin{array}{l}\text { Variabel } \\
\text { Manifest }\end{array}$ & Item Indikator Variabe \\
\hline Variabel La & n: Kepemimpinan keselamatan [KS] \\
\hline Visi & $\begin{array}{l}\text { 1. Mempunyai visi ke depan dalam } \\
\text { K3 [KS1] }\end{array}$ \\
\hline & $\begin{array}{l}\text { 2. Mampu menyampaikan visi } \\
\text { kepada anggota tim [KS2] }\end{array}$ \\
\hline 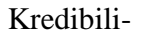 & ga kepercayaan [KS3] \\
\hline & 4. Kor \\
\hline $\begin{array}{l}\text { Orientasi } \\
\text { pada } \\
\text { tindakan }\end{array}$ & $\begin{array}{l}\text { 5. Memberikan teguran keras } \\
\text { terhadap risiko kurang memadai } \\
\text { [KS5] }\end{array}$ \\
\hline & $\begin{array}{l}\text { 6. Berbagi pengetahuan K3 dengan } \\
\text { anggota tim [KS6] }\end{array}$ \\
\hline & $\begin{array}{l}\text { 7. Memonitor fakta dan data yang } \\
\text { terukur dalam hal K3 kepada tim } \\
\text { [KS7] }\end{array}$ \\
\hline & $\begin{array}{l}\text { 8. Bertanggung jawab penuh } \\
\text { terhadap aktivitas atau pekerjaan } \\
\text { yang berbahaya di lapangan [KS8] }\end{array}$ \\
\hline Kolat & $\begin{array}{l}\text { 9. Mendorong anggota tim untuk } \\
\text { berpartisipasi aktif dalam } \mathrm{K} 3 \\
\text { [KS9] }\end{array}$ \\
\hline & $\begin{array}{l}\text { 10. Mengembangkan Kerjasama tim } \\
\text { untuk suatu keberhasilan [KS10] }\end{array}$ \\
\hline & $\begin{array}{l}\text { 11. Memberikan pengakuan pada } \\
\text { anggota tim dengan segera, pasti } \\
\text { dan berfikir positif [KS11] }\end{array}$ \\
\hline $\begin{array}{l}\text { Umpan } \\
\text { balik dan } \\
\text { pengakuan }\end{array}$ & $\begin{array}{l}\text { 12. Mendorong perilaku aman dan } \\
\text { umpan balik berdasarkan data } \\
\text { yang terukur, dapat diandalkan } \\
\text { dan sah [KS12] }\end{array}$ \\
\hline Variabel L & n: Komitmen Ahli K3 [KAK] \\
\hline Keselamat & apkan SMK3 [KAK1] \\
\hline $\begin{array}{l}\text { an dalam } \\
\text { tata nilai, } \\
\text { visi dan } \\
\text { misi }\end{array}$ & $\begin{array}{l}\text { 2. Menjalankan aktivitas K3 dengan } \\
\text { tanggung jawab, sepenuh hati dan } \\
\text { bersemangat [KAK2] }\end{array}$ \\
\hline $\begin{array}{l}\text { Keselamat } \\
\text { an dibahas }\end{array}$ & $\begin{array}{l}\text { 3. Membahas topik K3 dalam setiap } \\
\text { rapat [KAK3] }\end{array}$ \\
\hline $\begin{array}{l}\text { dalam } \\
\text { rapat }\end{array}$ & $\begin{array}{l}\text { 4. Mendiskusikan isu K3 dengan } \\
\text { anggota tim dan meminta umpan } \\
\text { balik [KAK4] }\end{array}$ \\
\hline $\begin{array}{l}\text { Dukungan } \\
\text { manaje- } \\
\text { men dan }\end{array}$ & $\begin{array}{l}\text { 5. Memberikan dukungan tenaga, } \\
\text { waktu dan pikiran untuk program } \\
\text { K3 berdasarkan prioritas [KAK5] }\end{array}$ \\
\hline sumber & 6. Berpendapat dan mendukung \\
\hline daya & 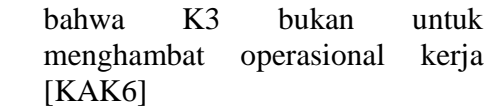 \\
\hline Keselamat & 7. Mendahulukan dan memastikan \\
\hline
\end{tabular}




\begin{tabular}{|c|c|}
\hline $\begin{array}{l}\text { Variabel } \\
\text { Manifest }\end{array}$ & Item Indikator Variabel Penelitian \\
\hline $\begin{array}{l}\text { an bagian } \\
\text { pengambil } \\
\text { an } \\
\text { keputusan }\end{array}$ & $\begin{array}{l}\text { keselamatan sebelum operasional } \\
\text { kerja dilakukan [KAK7] } \\
\text { 8. Memberikan teguran keras pada } \\
\text { operasional kerja dilapangan yang } \\
\text { berisiko bahaya [KAK8] }\end{array}$ \\
\hline \multicolumn{2}{|c|}{ Variabel Laten: Akuntabilitas [A] } \\
\hline $\begin{array}{l}\text { Komunika } \\
\text { si dan } \\
\text { manaje- } \\
\text { men } \\
\text { kepemimpi } \\
\text { nan }\end{array}$ & $\begin{array}{l}\text { 1. Ahli K3 dan tim diperusahaan } \\
\text { selalu mengadakan pertemuan } \\
\text { secara berkala, pelatihan dan } \\
\text { penyelesaian masalah K3 [A1] } \\
\text { 2. Ahli K3 dan tim diperusahaan } \\
\text { selalu menjamin komunikasi } \\
\text { dengan atasan, rekan kerja, pekerja } \\
\text { guna menjalankan SMK3 [A2] }\end{array}$ \\
\hline $\begin{array}{l}\text { Pengukur- } \\
\text { an efek } \\
\text { kerugian } \\
\text { akibat } \\
\text { kecelakaan } \\
\text { kerja }\end{array}$ & $\begin{array}{l}\text { 3. Perlu adanya pelatihan K3 untuk } \\
\text { mengurangi efek kerugian yang } \\
\text { lebih besar [A3] } \\
\text { 4. Memberikan pelatihan K3 bagi } \\
\text { karyawan secara berkala guna } \\
\text { menghindari terjadinya } \\
\text { Kecelakaan Kerja dan PAK [A4] }\end{array}$ \\
\hline $\begin{array}{l}\text { Penyebab } \\
\text { dasar } \\
\text { kecelakaan } \\
\text { kerja }\end{array}$ & $\begin{array}{l}\text { 5. Ahli K3 dan tim diperusahaan } \\
\text { peduli terhadap kegiatan lingkup } \\
\text { K3 dan mencari akar penyelesaian } \\
\text { masalah bila kondisi unsafe act } \\
\text { dan unsafe condition [A5] } \\
\text { 6. Ahli K3 dan tim diperusahaan } \\
\text { mendorong kepada karyawan guna } \\
\text { menjalankan SMK3 [A6] }\end{array}$ \\
\hline $\begin{array}{l}\text { Pendanaan } \\
\text { untuk } \\
\text { SMK3 }\end{array}$ & $\begin{array}{l}\text { 7. Memiliki pendanaan yang tersedia, } \\
\text { teratur, terukur untuk program K3 } \\
\text { [A7] } \\
\text { 8. Indikator kinerja akan dicapai, } \\
\text { ditetapkan dan digunakan untuk } \\
\text { mengevaluasi anggaran K3 [A8] }\end{array}$ \\
\hline \multicolumn{2}{|c|}{ Variabel Laten: Kepuasan kerja [KKJ] } \\
\hline $\begin{array}{l}\text { Pekerjaan } \\
\text { itu sendiri }\end{array}$ & $\begin{array}{l}\text { 1. Merasa puas bekerja diperusahaan } \\
\text { karena memiliki prosedur dan } \\
\text { peraturan SMK3 yang berlaku } \\
\text { [KKJ1] } \\
\text { 2. Merasa puas bekerja diperusahaan } \\
\text { sebelum bekerja mendapatkan } \\
\text { orientasi hal-hal berkaitan dengan } \\
\text { K3 [KKJ2] }\end{array}$ \\
\hline Atasan & $\begin{array}{l}\text { 3. Merasa puas kepada atasan dan } \\
\text { jajaran manajemen mengutamakan } \\
\text { dan menerapkan K3 [KKJ3] } \\
\text { 4. Merasa puas dengan atasan dan } \\
\text { jajaran manajemen karena } \\
\text { perhatian dan bertindak cepat bila } \\
\text { ada kejadian kecelakaan kerja } \\
\text { [KKJ4] }\end{array}$ \\
\hline $\begin{array}{l}\text { Teman } \\
\text { sekerja }\end{array}$ & $\begin{array}{l}\text { 5. Merasa puas dengan rekan kerja } \\
\text { memiliki kewajiban dan saling } \\
\text { mengingatkan terkait ketentuan } \\
\text { dan prosedur K3 [KKJ5] } \\
\text { 6. Merasa puas bekerja karena semua } \\
\text { karyawan memiliki pengetahuan } \\
\text { dan peduli tentang K3 [KKJ6] }\end{array}$ \\
\hline Promosi & $\begin{array}{l}\text { 7. Merasa puas untuk promosi } \\
\text { jabatan karena terdapat penilaian }\end{array}$ \\
\hline
\end{tabular}

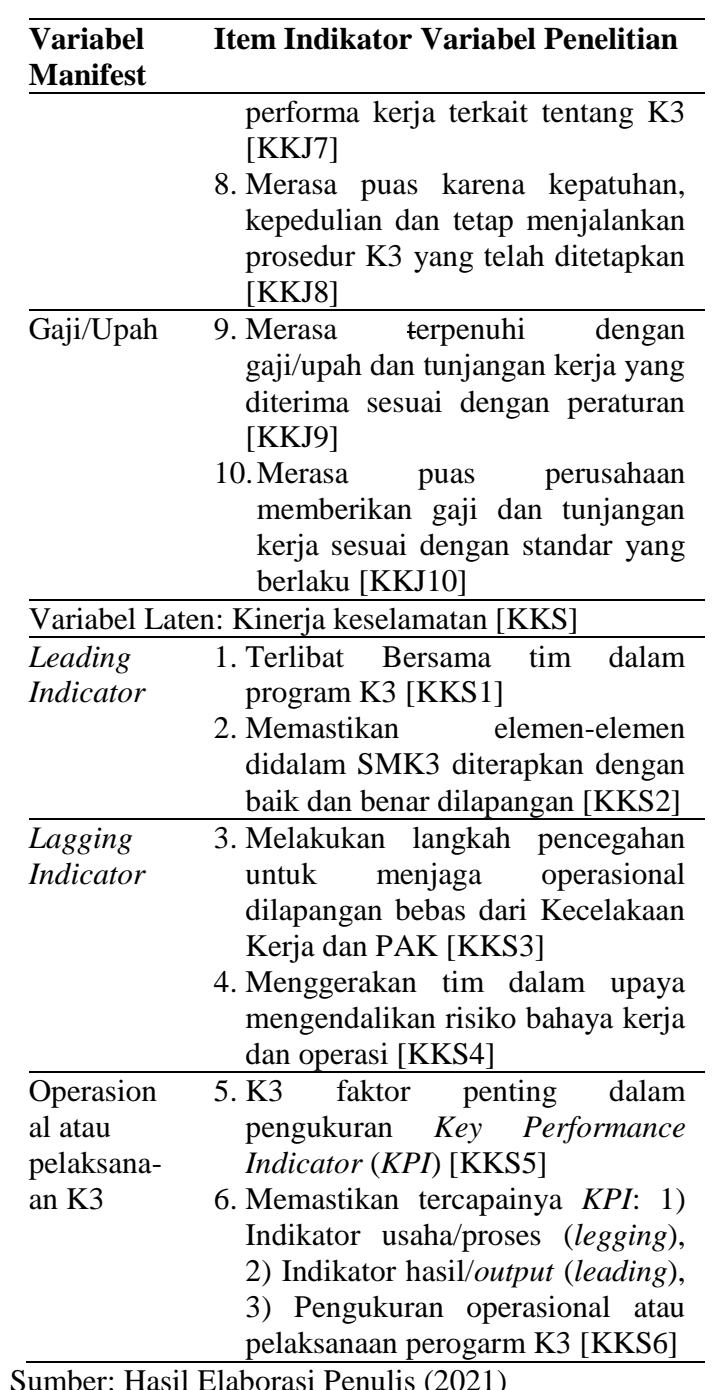

Sumber: Hasil Elaborasi Penulis (2021)

\section{PEMBAHASAN}

Berdasarkan hasil perhitungan SEMPLS, diperoleh hasil outer loading Kepemimpinan keselamatan [KS] yaitu KS_1 sampai dengan KS_12 mendapatkan nilai outer loading berkisar antara 0,851 - 0,948, outer loading Komitmen Ahli K3 [KAK] yaitu KAK_1 sampai dengan KAK_8 pada variabel Komitmen Ahli K3 mendapatkan nilai angka outer loading berkisar antara 0,804 - 0, 913, outer loading Akuntabilitas [A] yaitu A_1 sampai dengan A_8 pada variabel Akuntabilitas mendapatkan nilai angka outer loading berkisar antara 0,853 0,952, outer loading Kepuasan kerja [KKJ] yaitu KKJ_1 sampai dengan KKJ_10 pada variabel Kepuasan kerja mendapatkan nilai angka outer loading berkisar antara 0,848 0,934, outer loading Kinerja keselamatan [KKS] yaitu KKS_1 sampai dengan KKS_6 
pada variabel Kinerja keselamatan mendapatkan nilai angka outer loading berkisar antara $0,868-0,935$. Selengkapnya hasil estimasi model PLS disajikan pada Gambar 2.

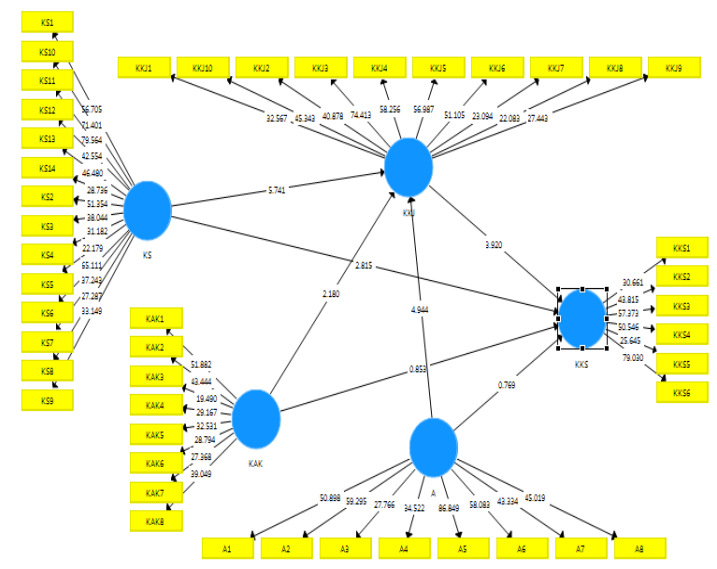

Keterangan:

KS: Kepemimpinan keselamatan, KAK: Komitmen Ahli K3, A: Akuntabilitas, KKJ: Kepuasan kerja; KKS: Kinerja keselamatan

\section{Gambar 2. Hasil estimasi model PLS}

Berdasarkan hasil perhitungan SEMPLS, diperoleh hasil bahwa perolehan pvalues untuk masing-masing variabel yang lebih kecil dari taraf nyata 0,05 , adapun untuk Komitmen ahli k3 terhadap kinerja keselamatan dan akuntabilitas terhadap kinerja keselamatan memperoleh p-values lebih besar dari taraf nyata 0,05. Selengkapnya disajikan pada Tabel 3.

\section{Kepemimpinan keselamatan terhadap kepuasan kerja}

Hasil perhitungan kepemimpinan keselamatan terhadap kepuasan kerja diperoleh pvalues sebesar 0,000 maka $(0,000$ $<\quad 0,05)$, menunjukan kepemimpinan keselamatan terbukti dapat memberikan dampak positif dan signifikan terhadap kepuasan kerja. Kepemimpinan keselamatan yang dilaksanakan dengan baik, maka kepuasan kerja semakin meningkat. Hasil penelitian sesuai dengan penelitian Marzuki et al. (2018) bahwa kepemimpinan keselamatan mampu memberikan pengaruh pada kepuasan kerja.

\section{Komitmen ahli K3 terhadap kepuasan kerja}

Hasil perhitungan kepemimpinan keselamatan terhadap kepuasan kerja diperoleh pvalues sebesar 0,030 maka $(0,030$ $<0,05)$, artinya komitmen ahli $\mathrm{K} 3$ terbukti dapat memberikan dampak positif dan signifikan terhadap kepuasan kerja. Komitmen ahli K3 yang dilaksanakan dengan baik, maka kepuasan kerja semakin meningkat. Hasil penelitian sesuai dengan penelitian Riswanto (2014) komitmen ahli K3 mampu memberikan pengaruh pada kepuasan kerja.

Tabel 3. Pengaruh Antar Variabel

\begin{tabular}{llll}
\hline $\begin{array}{l}\text { Pengaruh } \\
\text { antar variabel } \\
\text { yang diteliti }\end{array}$ & $p_{\text {values }}$ & $\begin{array}{l}\text { Keten- } \\
\text { tuan }\end{array}$ & Keterangan \\
\hline KS $\rightarrow$ KKJ & 0,000 & $<0,05$ & Signifikan \\
\hline KAK $\rightarrow$ KKJ & 0,030 & $<0,05$ & Signifikan \\
\hline $\mathrm{A} \rightarrow$ KKJ & 0,000 & $<0,05$ & Signifikan \\
\hline KS $\rightarrow$ KKS & 0,005 & $<0,05$ & Signifikan \\
\hline KAK $\rightarrow$ KKS & 0,394 & $>0,05$ & Tidak Signifikan \\
\hline $\begin{array}{l}\text { A } \rightarrow \text { KKS } \\
\text { KKJ } \rightarrow \text { KKS }\end{array}$ & 0,042 & $>0,05$ & Tidak Signifikan \\
\hline $\begin{array}{l}\text { KS } \rightarrow \text { KKJ } \\
\text { dampaknya } \rightarrow\end{array}$ & 0,001 & $<0,05$ & Signifikan \\
KKS & & & \\
\hline $\begin{array}{l}\text { KSK } \rightarrow \text { KKJ } \\
\text { dampaknya } \rightarrow\end{array}$ & 0,049 & $<0,05$ & Signifikan \\
KKS & & & \\
\hline $\begin{array}{l}\text { A } \rightarrow \text { KKJ } \\
\text { dampaknya } \rightarrow \\
\text { KKS }\end{array}$ & 0,003 & $<0,05$ & Signifikan \\
\hline & & & \\
\hline
\end{tabular}

\section{Akuntabilitas terhadap kepuasan kerja}

Hasil perhitungan akuntabilitas terhadap kepuasan kerja diperoleh pvalues sebesar 0,000 maka $(0,000<0,05)$, artinya akuntabilitas terbukti dapat memberikan dampak positif dan signifikan terhadap kepuasan kerja. Akuntabilitas yang dilaksanakan dengan baik, maka kepuasan kerja semakin meningkat. Hasil penelitian sesuai dengan penelitian Wardiana \& Hermanto (2018) bahwa akuntabilitas mampu memberikan dampak pada kepuasan kerja. 
Kepemimpinan keselamatan terhadap kinerja keselamatan

Hasil perhitungan kepemimpinan keselamatan terhadap kinerja keselamatan diperoleh pvalues sebesar 0,005 maka $(0,005$ $<0,05)$, artinya kepemimpinan keselamatan terbukti dapat memberikan dampak positif dan signifikan terhadap kinerja keselamatan. Kepemimpinan keselamatan yang dilaksanakan dengan baik, maka kinerja keselamatan semakin meningkat. Hasil penelitian sesuai dengan penelitian Mulyono et al. (2013) bahwa kepemimpinan keselamatan mampu memberikan dampak yang kuat pada kinerja keselamatan.

\section{Komitmen ahli K3 terhadap kinerja keselamatan}

Hasil perhitungan komitmen ahli K3 terhadap kinerja keselamatan diperoleh pvalues sebesar 0,394 maka $(0,394<0,05)$, artinya komitmen ahli K3 belum sepenuhnya terbukti dapat memberikan dampak positif dan signifikan terhadap kinerja keselamatan. Hasil penelitian ini berbeda dengan penelitian Riswanto (2014) bahwa komitmen organisasi memiliki dampak yang besar pada kinerja karyawan, begitu juga dengan penelitian Jamal et al. (2021) terdapat perbedaan yaitu komitmen berpengaruh positif terhadap kinerja.

\section{Akuntabilitas terhadap kinerja keselamatan \\ Hasil perhitungan akuntabilitas terhadap kinerja keselamatan diperoleh pvalues sebesar 0,442 maka $(0,442<0,05)$, artinya akuntabilitas belum sepenuhnya terbukti dapat memberikan dampak positif dan signifikan terhadap kinerja keselamatan. Hasil penelitian tidak sesuai dengan penelitian yang dilakukan oleh Wardiana dan Hermanto Riswanto (2019) bahwa akuntabilitas memberikan dampak pada kinerja organisasi.}

\section{Kepuasan kerja terhadap kinerja keselamatan}

Hasil perhitungan kepuasan kerja terhadap kinerja keselamatan diperoleh pvalues sebesar 0,000 maka $(0,000<0,05)$, artinya kepuasan kerja terbukti dapat memberikan dampak positif dan signifikan terhadap kinerja keselamatan. Kepuasan kerja dilaksanakan dengan baik, maka kinerja perusahaan meningkat. Hasil penelitian sesuai dengan penelitian Fajri et al. (2017) bahwa kepuasan kerja berdampak kuat pada kinerja karyawan perusahaan dan juga sesuai dengan penelitian Ruhayu (2020) bahwa kepuasan kerja berpengaruh positif dan signifikan terhadap kinerja.

\section{Kepemimpinan keselamatan terhadap kepuasan kerja dan dampaknya terhadap kinerja keselamatan}

Hasil perhitungan kepemimpinan keselamatan terhadap kepuasan kerja dan dampaknya pada kinerja keselamatan diperoleh pvalues sebesar 0,001 maka $(0,001$ $<0,05)$, yang berarti kepemimpinan keselamatan terbukti dapat memberikan dampak positif dan signifikan terhadap kepuasan kerja dan kinerja keselamatan. Kepemimpinan keselamatan dilaksanakan dengan baik, maka kepuasan kerja dan kinerja keselamatan semakin meningkat. Hasil penelitian sesuai dengan penelitian Mulyono et al. (2013) kepemimpinan mampu meningkatkan kepuasan kerja dan kinerja karyawan.

\section{Komitmen ahli K3 terhadap kepuasan kerja dan dampaknya terhadap kinerja keselamatan}

Hasil perhitungan komitmen ahli K3 terhadap kepuasan kerja dan dampaknya pada kinerja keselamatan diperoleh pvalues sebesar 0,049 maka $(0,049<0,05)$, artinya komitmen ahli K3 terbukti dapat memberikan dampak positif dan signifikan terhadap kepuasan kerja dan kinerja keselamatan. Komitmen ahli K3 dilaksanakan dengan baik, maka kepuasan kerja dan kinerja keselamatan semakin meningkat. Hasil penelitian sesuai dengan penelitian Riswanto (2014) bahwa komitmen organisasi mampu meningkatkan kepuasan kerja dan kinerja karyawan pada sebuah perusahaan.

\section{Akuntabilitas terhadap kepuasan kerja dan dampaknya terhadap kinerja keselamatan \\ Hasil perhitungan akuntabilitas} terhadap Kepuasan kerja dan dampaknya pada kinerja keselamatan diperoleh pvalues sebesar 
0,003 maka $(0,003<0,05)$, artinya akuntabilitas terbukti dapat memberikan dampak positif dan signifikan terhadap kepuasan kerja dan kinerja keselamatan. Akuntabilitas dilaksanakan dengan baik, maka kepuasan kerja dan kinerja keselamatan semakin meningkat. Hasil penelitian sesuai dengan penelitian (Radiyanto, 2018) bahwa akuntabilitas organisasi mampu meningkatkan kepuasan kerja dan prestasi kerja pegawai.

\section{SIMPULAN}

Hasil penelitian disimpulkan kepuasan kerja dipengaruhi secara signifikan oleh kepemimpinan keselamatan, komitmen ahli K3 dan akuntabilitas, begitu juga kinerja Keselamatan dapat dipengaruhi secara signifikan oleh kepemimpinan keselamatan atau kepuasan kerja. Sementara tidak ditemukan pengaruh yang signifikan komitmen ahli K3 dan akuntabilitas terhadap kinerja keselamatan, hal ini dikarenakan kurangnya komitmen para pekerja dalam penerapan dalam penerapan $\mathrm{K} 3$, begitu pula akuntabilitas belum sepenuhnya terbukti meningkatkan kinerja keselamatan, hal ini dikarenakan beberapa kegiatan yang belum dilakukan sepenuhnya sebagai bagian akuntabilitas Ahli K3.

Implikasi manajerial dari kajian yaitu dibutuhkan peningkatan kinerja keselamatan secara menyeluruh dan berkesinambungan dalam menjalankan kegiatan perusahaan, dengan cara memenuhi komitmen dan kepemimpinan yang kuat, manajemen harus menempatkan aspek K3 sebagai bagian integral dalam operasi perusahaan. Manajemen harus lebih memberikan arahan, menyediakan sumberdaya yang memadai untuk keselamatan, menetapkan standar kinerja berbasis keselamatan dan memberikan reward and punishment dalam pelaksanaan.

Saran penelitian selanjutnya dapat menambahkan variabel penelitian, misal pengukuran budaya $\mathrm{K} 3$, kompetensi, risiko keselamatan/bahaya dan sejenisnya.

\section{REFERENSI}

Agustina, S. S., \& Sukwika, T. (2021). Analisis kinerja pegawai pada direktorat sumber daya, ditjen dikti kemendikbud. Journal of Applied
Management Research, 1(1), 34-44. doi:10.36441/jamr.v1i1.263

Darmawan, A., \& Putri, M. A. (2017). Pengaruh Gaya Kepemimpinan terhadap Komitmen Organisasi Melalui Kepuasan Kerja Sebagai Variabel Intervening. Akuntabilitas: Jurnal Ilmu Akuntansi, 10(1), 2461-1190.

Fajri, K., Utami, H. N., \& Prasetya, A. (2017). Pengaruh Program Keselamatan dan Kesehatan Kerja (K3) terhadap Kepuasan Kerja dan Kinerja Karyawan (Studi pada Karyawan PT Brantas Abipraya (Persero) dalam Proyek Pembangunan Wisma Atlet Kemayoran). Jurnal Administrasi Bisnis, 46(1), 11-19.

Jamal, R. S., Firdaus, S., Bakhtiar, Y., \& Sanjaya, V. F. (2021). Pengaruh komitmen dan turnover intention terhadap kinerja karyawan. Jambura Economic Education Journal, 3(1), 3844. doi:10.37479/jeej.v3i1.8583

Kartikasari, S. E., \& Sukwika, T. (2021). Disiplin K3 melalui pemakaian alat pelindung diri (APD) di laboratorium kimia PT Sucofindo. VISIKES: Jurnal Kesehatan Masyarakat, 20(1), 41-50.

Kartikawati, M., Widjasena, B., \& Wahyuni, I. (2014). Pengaruh Kepemimpinan Keselamatan Pada Kepala Proyek Terhadap Angka Kecelakaan Kerja PT. $X$ Dan PT. Y Di Kota Solo Jawa Tengah. Jurnal Kesehatan Masyarakat (Undip), 2(5), 309-314.

Marzuki, H., Sularso, R. A., \& Purbangkoro, M. (2018). Pengaruh Budaya Keselamatan Kerja, Kepimimpinan Dan Motivasi Terhadap Kepuasan Kerja Dan Kinerja Karyawan Pada Perusahaan Minyak Dan Gas Bumi "X" Di Propinsi Kalimantan Timur. BISMA: Jurnal Bisnis dan Manajemen, 12(1), 51-65. doi:10.19184/bisma.v12i1.7601

Mulyono, K. (2013). Pengaruh Budaya K3 dan Gaya Kepemimpinan terhadap kepuasan kerja dan kinerja karyawan pada divisi operasi tambang di PT Newmont Nusa Tenggara. DiE: Jurnal Ilmu Ekonomi dan Manajemen, 9(1). 
Pramudya, A. G. (2018). Pengaruh Keselamatan dan Kesehatan Kerja (K3) Terhadap Kinerja Dengan Kepuasan Kerja Sebagai Variabel Intervening di Bagian Produksi PT. Pertamina (Persero) RU VI Balongan Indramayu.

Prasetyaningrum, D. (2020). Pengaruh Komitmen Organisasi, Karakteristik Pekerjaan Terhadap Kepuasan Kerja Karyawan dan Motivasi Kerja Sebagai Variabel Intervening. MANAJERIAL, $7(2)$, 155-169. doi:10.30587/manajerial.v7i2.1498

Purba, S. U., \& Sukwika, T. (2021). Pengaruh program keselamatan dan kesehatan kerja terhadap produktivitas kerja pada divisi proyek. Journal of Applied Management Research, 1(1), 67-77. doi:10.36441/jamr.v1i1.260

Radiyanto, R. (2018). Pengaruh Akuntabilitas dan Transparansi Terhadap Kepuasan Kerja Dengan Prestasi Kerja Pegawai Sebagai Variabel Antara. Jurnal Ekonomi dan Manajemen, 19(3), 44-59.

Ramli, S. (2010). Sistem Manajemen Keselamatan \& Kesehatan Kerja. Dian Rakyat, Jakarta.

Riswanto, E. (2014). Pengaruh komitmen organisasi terhadap kinerja melalui kepuasan kerja karyawan pada bank artha graha international tbk pekanbaru. Riau University,

Ruseffendi, E. (2010). Dasar-dasar penelitian pendidikan dan bidang non-eksakta lainnya. Bandung: Tarsito.

Satoto, H. F. (2020). Perspektif Safety Leadership dalam Peningkatan Kinerja Keselamatan Kerja. Heuristic, 17(1), 55-66. doi:10.30996/he.v17i1.3571

Sunarta, S. (2019). Pentingnya Kepuasan Kerja. Efisiensi: Kajian Ilmu Administrasi, 16(2), 63-75.

Wardiana, I. A., \& Hermanto, S. B. (2019). Pengaruh Akuntabilitas, Gaya Kepemimpinan, Kompetensi dan di Mediasi Motivasi Terhadap Kinerja Organisasi. Akuntabilitas, 12(1), 129144. doi:10.15408/akt.v12i1.12657

Widiarti, N. L. P. D., \& Dewi, A. S. K. (2016). Pengaruh Iklim Organisasi Dan
Kepuasan Kerja Terhadap Komitmen Organisasional Pada Dinas Pendapatan Provinsi Bali. E-Jurnal Manajemen Unud, 5(10), 6345-6372.

Zahra, N. (2015). Pengaruh Gaya Kepemimpinan Terhadap Komitmen Organisasi melalui aspek Kepuasan kerja karyawan dan kepercayaan pada sektor perbankan. Jurnal Manajemen dan Pemasaran Jasa, 8(1), 145-162. doi:10.25105/jmpj.v8i1.1406 